\title{
PROPERTY RIGHTS AND LEGITIMATE EXPECTATIONS UNDER UNITED STATES CONSTITUTIONAL LAW AND THE EUROPEAN CONVENTION ON HUMAN RIGHTS: SOME COMPARATIVE REMARIKS
}

\begin{abstract}
The present article aims to critically describe and compare how two rather different legal fora - the United States Supreme Court and the European Court of Human Rights address the same constitutional issue: the protection of property rights and legitimate expectations in the face of a legal change. According to the US Federal Constitution, the effects of a legal change over patrimonial interests can be treated under the due process of law clause or the takings clause. Article 1 of Protocol No. 1 of the European Convention on Human Rights, alone or in conjunction with the right to a fair trial, plays the same role under the ECHR. Our concluding remarks will show that in both systems, property protection provisions amount to a guarantee against unfair governmental action. Regulatory takings and proportionality are areas of strong disagreement between the two systems, whereas retroactive legislation and patrimonial expectations reveal some interesting similarities.
\end{abstract}

\section{Keywords}

legitimate expectations - property - United States Federal Constitution - European Convention on Human Rights - expropriation

* PhD Coimbra Faculty of Law; Lecturer in Católica University of Portugal, Porto Law School (mvicente@porto.ucp.pt). 


\section{INTRODUCTION}

The link between property rights and legitimate expectations is largely unsurprising. Current constitutional conceptions of property tend to include all kinds of legal rights with economic value. Apart from traditional forms of property (tangible assets), intellectual property rights, licences, and rights to certain amounts of money are also encompassed. What is more, as the present work will show, the guarantee of property amounts to a guarantee of an individual's overall financial condition. This converts the guarantee of property into a general standard of fairness, aimed at protecting that condition against manifold interferences, ranging from traditional takings to taxation, withdrawal of licences and exclusive rights or imposition of financial liabilities. ${ }^{1}$ Not all these "properties" benefit from the same vesting qualities or resistance against change, this being precisely the entry point of legitimate expectations in the property guarantee realm. A property owner holds a right against expropriation without compensation, but he holds nothing but an expectation against certain rules introducing restraints on the use of property. This is the tertium comparationis of the present comparative exercise: the impairment of patrimonial interests by a change in law.

The two systems explored in this study - US constitutional law and the ECHR - are hugely influential from a global standpoint. In fact, the Supreme Court's decisions on regulatory takings, especially Penn Central and Lucas, have seriously impacted investment treaty arbitration and investment treaty law in general. New investment treaties, like CETA or USMCA, ${ }^{2}$ make open references to "economic impact" or "investmentbacked expectations" ${ }^{3}$ - concepts distilled from the Supreme Court's caseload. The European Court of Human Rights (ECtHR), on the other hand, does not act as aggressively as other domestic or international legal systems in protecting economic power, wealth, and free market

1 T. Allen, Property and the Human Rights Act 1998, Hart Publishing, 2005, p. 146; S. Montt, State liability in investment treaty arbitration, Hart Publishing, 2012, p. 182.

2 EU-Canada Comprehensive Economic Trade Agreement (CETA); United States Mexico Canada Agreement (USMCA).

3 Annex 8-A of CETA; Annex 11-B of USMCA. 
policies. However, it is a powerful watch-dog of governments' behaviour towards individuals' possessions, ensuring that domestic authorities act in a credible and consistent manner. ${ }^{4}$ In addition, the European Court of Justice's protection of property draws largely upon the ECtHR's reading on article 1 of Protocol No. $1 .^{5}$

The first purpose of this article is to evaluate whether these systems are currently being structured and read in a way that enables them to accommodate a conception of property as a general standard of fairness. The second is to understand the meaning of legitimate expectations in the context of patrimonial interests. It seems crucial to discern whether the protection of patrimonial expectations gives emphasis to the government's course of action, or rather to the predictability and impact of legal change on investors. Lastly, we intend to grasp the strength of the protection afforded to individuals' legitimate expectations by calling attention to the way each system resorts to balancing exercises.

That said, whereas Part I of the present article focuses on United States (US) constitutional law, Part II points to the European Convention on Human Rights (ECHR). To accomplish the abovementioned objectives, both parts seek to describe the provisions based on which each system deals with legal changes affecting patrimonial expectations. Special attention will be awarded to recent trends in case-law, particularly concerning the standards of review and the key factors used in evaluating the predictability of a legal change.

Part III closes the article with an analysis of the system's key similarities and contrasts. Given the purposes of the text, it draws a comparative

${ }^{4}$ L. Cotula, "Expropriation clauses and environmental regulation: Diffusion of law in the era of investment treaties", Review of European, Comparative E International Environmental Law, Vol. 24, 2015, p. 278; A. B. Sanders, "Of all things made in America why are we exporting the Penn Central test?", Nw. J. L. \& Bus., Vol. 30, 2010, p. 339; M. Ruffert, "The protection of foreign direct investment by the European Convention on Human Rights", German Yearbook of International Law, Vol. 4, 2000, p. 116; U. Kriebaum, "Is the European Court of Human Rights an alternative to Investor-State arbitration?", in P. Dupuy, E. Petersmann, F. Francioni (eds.), Human Rights in International Investment Arbitration, Oxford, 2009, p. 219.

${ }^{5}$ M. R. Antinori, “Does Lochner live in Luxembourg? An analysis of property rights jurisprudence of the European Court of Justice", Fordham International Law Journal, Vol. 18, 1994, p. 1778. 
framework based on three criteria: the scope and structure of property protection provisions, the features of legitimate expectation, and, lastly, the role of proportionality and standards of review.

\section{The Protection of Property and Legitimate EXPECTATIONS UNDER US CONSTITUTIONAL LAW}

The US constitution offers both individuals and corporations several devices to assure their legitimate expectations in obtaining patrimonial assets in the face of federal, state or municipal legislative changes. These devices are ultimately two: $i$ ) the due process of law clause of the Fourteenth amendment to the US constitution, ${ }^{6}$ often employed in the review of retroactive and retrospective legislation; $i$ i) the takings clause, ${ }^{7}$ held in the Fifth amendment and originally understood as a guarantee of compensation when the government exercises its eminent domain.

\section{The Due Process of Law Clause}

To begin with, it is worth mentioning that the Supreme Court's jurisprudence does not ignore the difference between primary and secondary retroactivity, and that it upholds the interpretative guideline, endorsed by countless legal systems, regarding the presumption of nonretroactivity of laws. ${ }^{8}$ Therefore, in the absence of an explicit statement,

6 "No State shall make or enforce any law which shall abridge the privileges or immunities of citizens of the United States; nor shall any State deprive any person of life, liberty, or property, without due process of law; nor deny to any person within its jurisdiction the equal protection of the laws" (Fourteenth amendment, Section 1).

7 "Nor shall private property be taken for public use, without just compensation" (Fifth amendment). This study does not deal with the contract clause (article 1, section 10).

8 J. G. Laitos, "Legislative retroactivity", Wash. U. J. Urb. E Contemp. Law, Vol. 52, 1997, p. 81; L. Kaplow, "Transition Policy: A conceptual framework", Journal of Contemporary Legal Issues, Vol. 13, 2003, p. 161; M. J. Graetz, "Retroactivity revisited”, Harvard Law Review, Vol. 98, 1984, p. 98; J. Fish, "Retroactivity and Legal Change", Harvard Law Review, Vol. 110, 1997, p. 1063; A. C. Weiler, "Has due process struck out? The judicial rubberstamping of retroactive economic laws", Duke Law Journal, Vol. 41, 1992, p. 1076; A. Woolhandler, 
laws shall be interpreted as applying to future events. ${ }^{9}$ Suffice to say that retroactive and retrospective laws, by affecting the initial value of an asset, can impair investors' ability to take rational investment decisions and, thus, frustrate their legitimate expectations of profit.

The meaning currently attached to the due process of law clause comes from the Supreme Court's rejection of the Lochner jurisprudence, ${ }^{10}$ which was built on an intense scrutiny of the legislature's police powers, on the one hand, and, on the other, on an almost irrefutable presumption that freedom of contract should prevail over social and economic regulation. ${ }^{11}$ In fact, in the late nineteenth century the Supreme Court engaged in a substantive reading of the due process of law clause, which would foster, until the upcoming of New Deal, a case law premised on a constitutional reading which, by placing on the same level freedom of contract and other constitutional liberties, intended to scrutinise thoroughly the rationality behind the goals of the public powers instead of merely reviewing the rationality of the means chosen. ${ }^{12}$ The substantive due process was used to declare unconstitutional, not only policies regulating business entry, as succeeded in New State Ice Co. v. Liebmann, ${ }^{13}$ but also measures aimed at

"Public Rights Private Rights, and Statutory Retroactivity", The Georgetown Law Journal, Vol. 94, 2005, p. 1022.

9 Landgraf v. USI Film Prods., 511 U.S. 244 (1994).

${ }^{10}$ Lochner v. New York, 198 U.S. 45 (1905). The case dealt with a New York law setting the maximum hours that backers could work.

${ }^{11}$ R. J. Krotoszynski, "Expropriatory intent: Defining the proper boundaries of substantive due process and the takings clause", North Carolina Law Review, Vol. 80, 2002, p. 725; N. M. Merola, “Judicial review of State legislation: an ironic Lochnerian ideology when public sector labor contracts are impaired", St. John's Law Review, Vol. 84, 2010, p. 1181; T. B. Colby/P. J. Smith, “The return to Lochner”, Cornell Law Review, Vol. 100, 2015, p. 529; E. Chemerinsky, Constitutional Law: Principles and Policies, Aspen Publishers, 2011, p. 634; M. P. Harrington, "Foreword: The dual dichotomy of retroactive lawmaking", Roger Williams University Law Review, Vol. 3, 1997, p. 19; S. Pennicino, Contributo allo studio della ragionevolezza nel diritto comparato, Maggioli, 2012, 74; M. A. Schwartz, “A critical analysis of retroactive economic legislation: a proposal for due process revitalization in the economic arena", Seton Hall Constitutional Law Journal, Vol. 9, 1999, p. 946; L. H. Tribe, American Constitutional Law (vol. 1), Foundation Press, 2000, p. 1343.

12 Pennicino, supra note 11, p. 74; Chemerinsky, supra note 11, p. 644.

${ }^{13}$ New York Ice Co. v. Liebmann, 285 U.S. 262 (1932). 
protecting employees and consumers, as in Lochner or Adkins v. Children's Hospital. $^{14}$

This understanding was strongly condemned by Justice Holmes, whose dissenting opinion in Lochner is often quoted: "a Constitution is not intended to embody a particular economic theory, whether of paternalism and the organic relationship of the citizen to the State or of laissez-faire" ${ }^{15}$ In fact, in the case that sealed the end of the Lochner era - Nebbia v. New York ${ }^{16}$ - the Supreme Court clearly addressed the judicial activism rationale underlying Justice Holmes' dissent in Lochner, by stating that "in the absence of other constitutional restraints, a state is free to adopt whatever economic policy may reasonably be deemed to promote public welfare".

The end of the so-called Lochner era is pivotal to fully understand why, nowadays, apart from the political and civil rights sector, the due process of law clause entails no more than a deference control towards government measures, standardly known as the "rational basis test" or "minimal scrutiny". ${ }^{17}$ According to this standard, only measures not rationally established would be unconstitutional.

A higher standard of review is not required even in relation to retroactive or retrospective tax legislation. ${ }^{18}$ In the first place, retroactive tax legislation is less prejudicial in terms of detrimental reliance. That is to say that, since tax laws do not typically seek to encourage or to discourage economic behaviour, it is not likely that individuals or corporations have altered their behaviour in the face of a prior piece of legislation. ${ }^{19}$ Secondly, retroactive legislation is frequently a legislative necessity,

14 Adkins v. Children's Hospital, 261 U.S. 525 (1923).

15 Lochner v. New York, supra note 10.

${ }^{16}$ Nebbia v. New York, 291 U.S. 502. See also United States v. Carolene Products, 304 U.S. 144 (1938), known for openly supporting a rational basis test when reviewing economic regulations: "the existence of facts supporting the legislative judgment is to be presumed, for regulatory legislation affecting ordinary commercial transactions is not to be pronounced unconstitutional unless, in the light of the facts made known or generally assumed, it is of such a character as to preclude the assumption that it rests upon some rational basis within the knowledge and experience of the legislators".

17 Pennicino, supra note 11, p. 116.

18 Schwartz, supra note 11, p. 946; Weiler, supra note 8, p. 1070.

19 Welch v. Henry et al., 305 U.S. 134 (1938). 
stressed by the need to recover excessive profits engendered by legislative failures - the so-called "loopholes" - and to achieve information regarding the sources of tax responsibility. However, this argument can only be endorsed provided that the retroactivity is short in time and adequate to meet that necessity, ${ }^{20}$ the best example being United States $v$. Carlton. ${ }^{21}$

Legislative interference with pending cases is also an issue under the due process clause. In United States v. Schooner Peggy, 22 the Supreme Court announced the precedent still governing the topic, according to which courts, whether trial or appellate, should apply the law that exists at the time the decision is issued irrespective of whether that law existed at the time the lawsuit was initiated. This rule - the so-called "changed law rule" - knows certain limitations imposed largely by the need to protect the parties' reliance on previous law, ${ }^{23}$ and, less frequently, by the separation of powers rationale. ${ }^{24}$

That is why to avoid Lochnerisation criticism, courts intending to review economic legislation under a more stringent standard would resort to other constitutional devices, such as the takings clause.

\section{The Takings Clause}

Just as in continental law, the compensation guarantee in case of expropriation is premised on the principle of equality as to the public charges. The argument is that compensation prevents governments from requiring some people alone to bear public burdens, which in all fairness and justice should be borne by the public as a whole..$^{25}$ The takings clause offers protection not only against cases where the government uses its formal expropriation powers - the so-called eminent domain - but also against regulatory taking cases, i.e. cases where government regulation

\footnotetext{
${ }^{20}$ Weiler, supra note 8, p. 1109.

${ }^{21}$ United States v. Carlton. 512 U.S. 26 (1994). See also Justice Scalia dissenting.

22 United States v. Schooner Peggy, 5 U.S. 103 (1801).

${ }^{23}$ Chase Securities Corporation v. Donaldson, 325 U.S. 304 (1945); Campbell v. Holt, 115 U.S. 620 (1885); Landgraf v. USI Film Products (note 9).

${ }^{24}$ United States v. Klein, 80 U.S. 128 (1871).

25 See, for example, Armstrong v. United States, 364 U.S. 40 (1960).
} 
of private property is so onerous that its effect is tantamount to a direct expropriation.

Therefore, the key issue for the courts to settle is whether a regulatory change produces effects tantamount to an expropriation, given that the establishment of that equivalence entails the duty to compensate. $U$. Kriebaum rightfully stresses that this train of thought relies on "all or nothing" reasoning. ${ }^{26}$

At first, the Supreme Court opted not to give in advance any fixed set of rules concerning the finding of that equivalence. Justice Holmes has provided some guidance in Pennsylvania Coal Co. v. Mahon, ${ }^{27}$ by holding that a taking takes place whenever government regulation "goes too far". In Lingle $v$. Chevron, ${ }^{28}$ after almost a century of jurisprudential developments, the Supreme Court confirmed the existence of a particular type of regulatory takings - the so-called per se or categorical takings which occur in view of regulations that entail physical intervention by government, ${ }^{29}$ or that eliminate all economically viable beneficial use of property. Outside this narrow realm, the court favours a casuistic assessment based on criteria that require a high amount of judicial discretion. ${ }^{30}$

${ }^{26} U$. Kriebaum, "Regulatory Takings: Balancing the interests of the investor and the State", Journal of World Investment E Trade, Vol. 8, 2007, p. 719.

${ }^{27}$ Pennsylvania Coal Co. v. Mahon, 260 U.S. 393 (1922).

${ }^{28}$ Lingle v. Chevron, 544 U.S. 528 (2005).

29 Pumpelly v. Green Bay Co., 80 U.S. 166 (1871); Northern Transportation Co. v. Chicago, 99 U.S. 635 (1879); Loretto v. Teleprompter Manhattan CATV Corp., 458 U.S. 419 (1982).

${ }^{30}$ Chemerinsky, supra note 11, p. 667; J. N. Bunch, "Takings, judicial takings, and patent law", Texas Law Review, Vol. 83, 2005, p. 1751; M. C. Sochacki, “Takings law: the similarities and differences between the European Court of Human Rights and the United States Supreme Court", Connecticut Journal of International Law, Vol. 24, 2009, p. 435; C. M. Rose, "Mahon reconstructed: why the takings issue is still a muddle", Southern California Law Review, Vol. 57, 1984, p. 566; F. McCubbins, "Regulatory takings: What did Penn Central hold? Three decades of Supreme Court explanation", Southern Law Journal, Vol. 21, 2011, p. 186; S. J. Eagle, "Penn Central and its reluctant muftis", Baylor Law Review, Vol. 66, 2014, p. 1; J. W. Singer, "Regulatory Takings", Ohio Northern University Law Review, Vol. 41, 2014, p. 601; W. A. Fischel, Regulatory Takings: Law, Economics and Politics, Harvard University Press, 1995. 


\subsection{Penn Central's Tests}

The criteria were brought about in Penn Central Transportation Co. v. New York City, ${ }^{31}$ a case dealing with urban planning and cultural heritage. Briefly, the appellant claimed that the refusal, by New York City, of a permit for building over the Grand Central Terminal - a building which was previously designated, under New York City's Landmarks Preservation Law, as a "landmark" 32 - effected a taking of its property without just compensation. Though stating that the assessment would ultimately depend on an ad hoc factual inquiry, the Supreme Court put forward three relevant criteria, viz. the economic impact of the regulation, the extent to which the regulation interfered with distinct investmentbacked expectations, and the nature or character of the governmental regulation. The conclusion held by the Court was that no taking had occurred and, therefore, no compensation was due to the appellant. The Court highlighted:

"The submission that appellants may establish a taking simply by showing that they have been denied the ability to exploit a property interest that they heretofore had believed was available for development is quite simply untenable (...). This Court focuses rather both on the character of the action and on the nature and extent of the interference with rights in the parcel as a whole."

\subsubsection{The Character of the Governmental Regulation}

The character of the governmental course of action intends to shed light on the public interest that the measure is aimed to achieve. The fact that the government is exercising its police powers, by ensuring the "protection of the lives, health and property of the citizens and the preservation of

31 Penn Central Transportation Co. v. New York City, 438 U.S. 104 (1978).

${ }^{32}$ Under New York City's landmark preservation law, the owner of a landmark building must keep the building's exterior in good repair and seek the Commission's approval before exterior alterations are made. 
good order and the public morals" ${ }^{\prime 33}$ holds a negative but merely indicative value in assessing whether a taking has taken place.

In other words, when the legislature puts into effect a programme "adjusting the benefits and burdens of economic life to promote the common good", courts rarely find a taking. ${ }^{34}$ This is so because these measures are envisaged as restraints on the use of property that are tantamount to public nuisances, i.e. as measures asking investors to address the costs of using the property in a certain way. ${ }^{35}$ For example, in Miller $v$. Schoene, the court held that the compulsory cut down of red cedar trees due to a communicable plant disease did not amount to a taking. In fact, "where the public interest is involved, preferment of that interest over the property interest of the individual, to the extent even of its destruction, is one of the distinguishing characteristics of the police power" ${ }^{36}$ However, Justice Rehnquist's dissent in Keystone ${ }^{37}$ suggests that the nuisance rationale is different and narrower from the police powers doctrine, and that not every regulation based on essentially economic concerns should be insulated from the dictates of the Fifth amendment. ${ }^{38}$

On the other hand, in Lingle, the Supreme Court reversed the precedent brought about in Agins v. City of Tiburon, ${ }^{39}$ which assumed that the character of the governmental action should have a positive and mandatory value in the quest for a taking. This doctrine - known as the "substantive advances formula" - posits that a government regulation

33 Beer Company v. Massachusetts, 97 U.S. 25 (1877).

${ }^{34}$ See, among others, Goldblatt v. Town of Hempstead, 369 U.S. 590 (1969); Keystone Bituminous Coal Ass'n v. DeBenedictis, 480 U.S. 470 (1987); Miller v. Schoene, 276 U.S. 272 (1928); Consolidated Rock Products v. City of Los Angeles (1962); Hadacheck v. Sebastian, 239 U.S. 394 (1915); Reinman v. Little Rock, 237 U.S. 171 (1915).

35 Fischel, supra note 30, p. 22 ("if a land use is itself noxious, dangerous, or causes a public nuisance, the legislature is free to regulate its use without compensation, even though the police power may cause great loss to property owner").

${ }^{36}$ Miller $v$. Schoene (supra note 42) [emphasis added].

${ }^{37}$ Keystone Bituminous Coal Ass'n v. DeBenedictis (supra note 34).

${ }^{38}$ Lucas v. South Carolina Coastal Council, 505 U.S. 1003 (1992), also raises the question when noting that "the transition from our early focus on control of noxious uses to our contemporary understanding of the broad realm within which government may regulate without compensation was an easy one, since the distinction between harm preventing and benefit conferring regulation is often in the eye of the beholder" [emphasis added].

39 Agins v. City of Tiburon, 447 U.S. 255 (1980). 
that does not substantially advance legitimate state interests amounts to an unconstitutional regulatory taking, irrespective of the magnitude of the burden it imposes upon private property rights. In Lingle, though, the court reinforced the weight of the three Penn Central's criteria, by highlighting that, even if the government's policy proves to be inefficient, no taking occurs without carefully considering the "actual burden imposed on property rights". ${ }^{40}$

\subsubsection{INVESTMENT-BACKED EXPECTATIONS}

Recognizing a taking rests also on the extent to which the regulation interferes with investors' distinct investment-backed expectations. This tenet, which is also present in investment arbitration and ECtHR case law, has to do with feasible - i.e., viable - expectations of gain that might reasonably be expected to emerge from the investment before the regulatory change was enacted.

Feasibility and reasonableness are crucial for fulfilling this test. To begin with, the feasibility of an expectation varies according to the stability and instability of the economic sector at stake. ${ }^{41}$ Despite the opacity of the judicial criteria, the Supreme Court provided, in Guggenheim v. City of Goleta, ${ }^{42}$ some insight on the subject by stating that "distinct investmentbacked expectations" means "reasonable probability" of obtaining a certain amount of income. By this token, the Court reveals its preference for a legal criterion, based on the feasibility of expectations evidenced by permits, promises, and public contracts, ${ }^{43}$ rather than mere opportunities of profit. Speculative profits and expectations contrary to the legal system are similarly not worth protection. On the same judgment, when deciding whether a change in rent control for mobile homes effected a taking, the Court pointed out that the ordinance intended to grapple with exorbitant

${ }^{40}$ Lingle v. Chevron (supra note 28).

${ }^{41}$ Fisch, supra note 8, p. 1108.

${ }^{42}$ Guggenheim v. City of Goleta (9th Circ. Dec. 22, 2010) [emphasis added]. See also Andrus v. Allard, 444 U.S. 51 (1979) ["prediction of profitability is essentially a matter of reasoned speculation that courts are not especially competent to perform"].

${ }^{43}$ Singer, supra note 30, p. 650. 
rents during a period of a shortage of housing ["Speculative possibilities of windfalls do not amount to distinct investment-backed expectations (...)»].

Insofar as "distinct investment-backed expectations" are related to the probability of earning income by means of exploring the attributes inherent to property rights, special attention must be paid to occasions when the hindrance of these features unveils the event of a taking.

When assessing the Penn Central's criteria, the Supreme Court sets a high threshold for concluding that investment-backed expectations have been breached. It argues that breach occurs only if the regulation seizes some essential feature of the investment, or, alternatively, if the regulation removes the investor's ability to obtain a reasonable return on his investment. In Keystone Bituminous Coal Ass' $n$ v. DeBenedictis, ${ }^{44}$ the Supreme Court focused on quantifying the loss of profit imposed by the regulatory change so as to ascertain whether the investment remained economically viable.

Despite its recurrent usage, the economic profitability criterion is far from having unanimous approval within the Supreme Court, as it cast doubts upon what is the proper denominator in the takings fraction. ${ }^{45}$

\subsubsection{The ECONOMIC IMPACT OF THE REgUlation AND LUCAS PER SE TAKING}

Keystone suggests an overlap between investment-backed expectations and the economic impact of the regulation. This is because whenever the court finds an interference with investment-backed expectations, or, in other words, the destruction of the investment's productive viability, the regulation's burdensome impact upon investment becomes self-evident.

${ }^{44}$ Keystone Bituminous Coal Ass'n v. DeBenedictis (supra note 42).

${ }^{45}$ Keystone Bituminous Coal Ass'n v. DeBenedictis (supra note 42), Justice Rehnquist's dissent opinion, joined by Justices Powell, O'Connor, and Scalia. Justice Rehnquist argued that the Court's approach should be to evaluate a taking claim "by reference to the units of the property defined by state law", instead of assessing it "by reference to some broader, yet undefined segment of property presumably recognized by state law". See also Lucas v. South Carolina Coastal Council (supra note 46), footnote 7, and Palazzolo v. Rhode Island, 533 U.S. 606 (2001). P. C. McGinley, “Bundled rights and reasonable expectations: applying 
Nonetheless, this criterion acquires an autonomous significance when the court concludes that the regulation completely deprives the owner of all economically beneficial use of the property. The so-called "sole effects doctrine" came about in Lucas v. South Carolina Coastal Council. ${ }^{46}$ It dealt with an act - the Beachfront Management Act - that barred the petitioner from erecting any permanent habitable structures on his South Carolina barrier island's property. The Supreme Court called attention to the fact that the regulation target or character ought not to undermine the duty to pay compensation in cases where the regulation "has deprived the landowner of all economically beneficial uses", since these cases evidence "a heightened risk that private property is being pressed into some form of public service under the guise of mitigating serious public harm".

Despite the global concerns that have erupted worldwide, particularly regarding the constraints on the government's right to exercise its police powers ${ }^{47}$ the Lucas per se taking remains statically insignificant. ${ }^{48}$ In fact, depriving the property owner of its most beneficial use is not tantamount to eliminating all reasonably economically viable use of that property. The factual ground of Lucas remains contentious, as it has been argued that the landowner could still sell its property at a reasonable price. ${ }^{49} \mathrm{In}$ Palazzolo $v$. Rhode Island, ${ }^{50}$ a case dealing with permanent rejection, by

the Lucas categorical taking rule to severed mineral property interests", Vermont Journal of Environmental Law, Vol. 11, 2010, p. 533; Rose, supra note 30, p. 566.

${ }^{46}$ Lucas v. South Carolina Coastal Council (supra note 46).

${ }^{47}$ R. Dolzer, "Indirect expropriations: new developments?", N.Y.U. Environmental Law Journal, Vol. 11, 2002, p. 79; R. Dolzer/F. Bloch, "Indirect expropriations: Conceptual realignments?", International Law Forum, Vol. 5, 2003, p. 163; Y. Fortier/S. L. Drymer, "Indirect expropriation in the law of international investment: I know it when I see It, or Caveat Investor", Asia Pacific Law Review, Vol. 13, 2005, p. 93; S. Olynyk, "A balanced approach to distinguishing between legitimate regulation and indirect expropriation in investor-state arbitration", Int'l Trade \& Business Law Review, Vol. 15, 2002, p. 256; Kriebaum, supra note 26, p. 724; C. Henckels, "Indirect Expropriation and the right to regulate: Revisiting proportionality analysis and the standard of review in investor-state arbitration", Journal of International Economic Law, Vol. 15, 2012, p. 223.

${ }^{48}$ R. J. Lazarus, "Lucas unspun”, Southeastern Environmental Law Journal, Vol. 16, 2008, p. 26.

${ }^{49}$ Ibid. p. 18.

${ }^{50}$ Palazzolo v. Rhode Island (supra note 54). See also Andrus v. Allard (supra note 50), handling a prohibition on commercial transactions in eagle feathers. The Supreme Court 
zoning authorities, of the owner's development proposals of a parcel of land designated as "coastal wetlands", the Supreme Court emphasized that "a regulation permitting a landowner to build a substantial residence on an 18-acre parcel does not leave the property economically idle".

By definition, a categorical taking refers to situations where compensation is due regardless of the character, nature, or justification behind the governmental measure. This was openly admitted in cases dealing with physical invasions, such as Loretto, which held that a permanent physical occupation of property constitutes a taking "without regard to whether the action achieves an important public benefit or has only minimal economic impact on the owner". Even though from the landowner's standpoint a regulation encompassing Lucas's features is the "equivalent of physical appropriation", ${ }^{1}$ the reasoning underlying physical invasion takings is not fully transposable to Lucas.

In fact, the Court has simultaneously undermined Lucas's bright line rule by setting that a regulation that leaves property economically idle does not entail compensation provided that the limitation in question is inherent to the title itself, working as background principle that the State's law of property and nuisance already placed upon landownership. Legal scholars argue that Lucas segregates one of Penn Central's tests the economic impact of the measure - by stressing its sufficiency to infer that a taking has emerged, ${ }^{52}$ or similarly, by a priori settling a normative conflict in favour of the duty to compensate. Given the definition of categorical takings endorsed by the Supreme Court, these assertions seem undisputable. However, the "already placed" nuisance exception to Lucas, coupled with its highly-demanding factual background, undermine the operative value of this per se rule.

stated that, although the prohibition prevented the most profitable use of the appellees' property, no taking had occurred insofar as they "retain the rights to possess and transport their property, and to donate or devise the protected birds".

${ }^{51}$ Loretto v. Teleprompter Manhattan CATV Corp. (supra note 29).

52 Fischel, supra note 30, p. 59 ("there are some regulatory schemes so close in spirit to eminent domain that they must be regarded as takings."); Singer, supra note 30 at p. 633 ("the Lucas rule against deprivation of all economically viable use is simply an extreme application of the economic impact factor"); M. Perkmans, "The concept of indirect 


\subsection{The sCope of CONStitutional Property: EASTERN ENTERPRISES}

As previously mentioned, a recent trend in the Fifth amendment case law has been its role in cases dealing with non-conventional property rights. This does not come as a surprise given the expansion that property rights have undergone. They include traditional property rights over tangible assets, as well as contractual and intellectual property rights, ${ }^{53}$ or, to sum up, any right capable of being object of a commercial transaction. ${ }^{54}$

However, doubts have been cast upon the defensibility of using the Fifth amendment for assessing claims that ordinarily would fit into the due process of law clause. At issue are those cases in which, having due regard to the nature of the government's measure, it makes little sense to use a normative device whose consequence is the duty to pay compensation rather than the annulment of the measure. ${ }^{55}$ Further, this path suggests that the Fifth amendment is no longer just a standard used for controlling the government's eminent domain power, but also a general guarantee against arbitrary, especially retroactive, legislation.

Eastern Enterprises v. Apfel, ${ }^{56}$ for instance, dealt with the introduction of a fund aimed at providing health benefits to coal industry workers and to their dependents. The fund was to be financed by any coal operator, whether or not in the coal industry, including by Eastern Enterprises, a company who had left the industry in the early sixties. The Supreme Court concluded for the unconstitutionality of the act, and four out of nine judges support the verification of Penn Central's tests. Regarding the

expropriation in comparative public law - searching for light in the dark", in S. W. Schill (eds.), International Investment Law and Comparative Public Law, Oxford, 2008, p. 107.

${ }^{53}$ Ruckelshaus v. Monsanto Co., 467 U.S. 986 (1984); Webb's Fabulous Pharmacies, Inc. v. Beckwith, 449 U.S. 155 (1980); Festo Corp. v. Shoketsu Kinzoku Kogyo Kabushiki Co., 535 U.S. 722 (2002).

${ }^{54}$ P. C. Choharis, "U.S. Courts and the international law of expropriation: toward a new model for breach of contract", Southern California Law Review, Vol. 80, 2007, p. 15; Woolhandler, supra note 8, p. 1015; Bunch, supra note 30, p. 1747.

${ }_{55}$ Krotozynski, supra note 14, p. 723.

56 Eastern Enterprises v. Apfel, 524 U.S. 498 (1998). 
economic impact of the measure, the Court - in contradiction with former case law - held that the responsibility Eastern was called to bear was substantial, in the sense that it would deprive the company of the amounts covered by the fund. The event of a taking was not eroded by the fact the government had not specified the assets required to satisfy the pecuniary obligation. In our opinion, this a rather useless assertion inasmuch as any investor called upon to pay a pecuniary obligation is deprived of the amounts needed to comply with it. Moreover, the Court's reasoning in Eastern seems to recover the "conceptual severance", a doctrine openly rejected in Penn Central57 and that obstructs government's chances of winning a Fifth amendment case. ${ }^{58}$

\subsection{Regulatory Takings: How Many Standards?}

Our analysis of the character of the governmental regulation test has revealed a consistent engagement with a reasonableness standard of scrutiny, based on the assumption that the government's exercise of its police powers is presumed to be constitutionally valid. In line with Consolidated Rock Products, this is a clear recognition of the "principle of the division of functions between the legislative and judicial branches" ${ }^{59}$

Occasionally, though, considering that the Fifth amendment calls for an assessment of the burden that the law has imposed upon a few individuals, ${ }^{60}$ the Supreme Court goes for a heightened standard of review. This is true for urban law exactions, which occur when the government makes the issuance of building permits depend on the performance of certain non-straightforward conditions. ${ }^{61}$

57 Penn Central Transportation Co. v. New York City (note 31) [“takings jurisprudence does not divide a single parcel into discrete segments and attempt to determine whether a particular governmental action had effected a taking"].

58 S. Montt, supra note 1, p. 189; Fischel, supra note 30, p. 49.

59 Consolidated Rock Products v. City of Los Angeles (supra note 34).

${ }^{60}$ Singer, supra note 30, p. 636.

${ }^{61}$ Dolan v. City of Tigard, 512 U.S. 374 (1994). See also Nollan v. California Coastal Commission, 483 U.S. 825 (1987), where the Supreme Court assessed the constitutionality of the granting of a permit, by the California Coastal Commission, upon the condition that the appellants allow the public an easement to pass across their beach. 
In Dolan v. City of Tigard ${ }^{62}$, the authorities decided that a building permit was contingent on the construction, by the plaintiffs, of a pedestrian pathway, which would solve some current traffic problems. When finding whether a taking had occurred, the Supreme Court stressed that it was pivotal to know "whether the essential nexus exists between the legitimate state interest and the permit condition" and, additionally, in resemblance to proportionality in the narrow sense, whether "the degree of the exactions demanded by the city's permit conditions bear the required relationship to the projected impact of petitioner's proposed development". ${ }^{63}$

The premise of this heightened standard is that in Dolan, as well as in Nollan ${ }^{64}$, the exactions would have constituted a categorical taking (physical invasion) if imposed irrespectively of the granting of the building permit. By demanding a "reasonable relationship" between the exactions and the interests that land authorities sought to pursue, the court overtly asked for a standard tougher than the rational basis test, namely a "rough proportionality" test. ${ }^{65}$

Subsequent cases have revealed the extent to which the Supreme Court intends to apply this new and more substantial standard of scrutiny. In City of Monterey v. Del Monte Dunes ${ }^{66}$, confronted with the successive rejection by the land authority, of the property owner's proposals to develop the property, coupled with the imposition of demanding exactions, the court refused to apply the Nollan/Dolan rough proportionality test, thereby stressing that the latter only targets cases

${ }^{62}$ Dolan v. City of Tigard (supra note 61).

${ }^{63}$ Fischel, supra note 30, p. 58 ["On this rule, a community could give an exception to a leash law to dog owners who contributed to clean-up fund, but it could not give an exception to dog owners who promised to paint their houses white"].

${ }^{64}$ Nollan v. California Coastal Commission (supra note 61) ["had California simply required the Nollans to make an easement across their beachfront available to the public on a permanent basis in order to increase public access to the beach, rather than conditioning their permit to rebuild their house on their agreeing to do so, we have no doubt there would have been a taking"].

${ }^{65}$ J. D. Echeverria, "Koontz: the very worst takings decision ever?", N.Y. University Environmental Law Journal, Vol. 22, 2015, p. 6; McCubbins, supra note 30, p. 186; Chemerinsky, supra note 11, p. 681.

${ }^{66}$ City of Monterey v. Del Monte Dunes, 526 U.S. 687 (1999). 
where a building permit is issued following the landowner's acceptance of the (excessive) exactions. Recently, however, in Koontz v. St. Johns River Water Management District, the City of Monterey precedent was reversed, as the court held that resorting to Nollan/Dolan principles was not dependent, firstly, on whether the government approved or denied a permit, and, secondly, on whether the exactions imposed concerned a parcel of land or involved rather the payment of money. Underlying this enlargement is the need to prevent governments from evading the Nollan/Dolan rationale in situations where, notwithstanding its financial character, the exaction bears a special connection with a specific parcel of real property. ${ }^{67}$

The decision raises many doubts and thorough concerns. ${ }^{68}$ For instance, if monetary exactions are thereafter subject to the rough proportionality test, how to distinguish them from property taxes, which would be normally assessed under the rational basis test? If the monetary exaction works as a per se taking, because of the link established with a specific parcel of land, why run the Nollan/Dolan inquiries at all? ${ }^{69}$

The Koontz decision, coupled with Eastern Enterprises and the reversal of City of Monterrey, embody an expansionary trend in takings clause jurisprudence. It operates, firstly, through the adoption of a heightened standard of review in urban law, which narrows the measures taken as restraints on the use of property not requiring compensation, and secondly, by means of including the imposition of monetary responsibilities in the regulatory takings realm. Although this trend is not ignored in other legal systems, ${ }^{70}$ particularly in those not admitting a substantive due

${ }^{67}$ Koontz v. St. Johns River Water Management District, 530 U.S. (2013) ["because of the direct link between the government's demand and a specific parcel of real property, this case implicates the central concern in Nolan and Dollan: the risk that the government may deploy its substantial power and discretion in land-use permitting to pursue governmental ends that lack an essential nexus and rough proportionality to the effects of the proposed use of the property at issue"].

${ }^{68}$ Echeverria, supra note 65, p. 6; I. Piedra, "Confusing regulatory takings with regulatory exactions: the Supreme Court gets lost in the swamp of Koontz", Environmental Affairs, Vol. 41, 2014, p. 555. See also Justice Kagan's dissent opinion in Koontz.

${ }^{69}$ Echeverria, supra note 65, p. 41.

70 See Part III. 
process reading, it is still somewhat disturbing since it might work as a disguised surrogate of a less-deferral due process clause. ${ }^{71}$ Plus, the financial consequences of such approach could be burdensome, owing to the takings clause inflexible all-or-nothing approach to regulatory takings.

\section{SUMmary OF PARTY I}

Despite their different constitutional location and historical background, the due process clause and the takings clause are alternative texts, in the sense that they can be mobilize to address the same constitutional issue - legislative interferences with legitimate expectations - by means of different remedies and standards of scrutiny.

We highlighted that, since the end of the Lochner era, the Supreme Court has attached socio-economic legislation with a presumption of constitutionality, meaning that it will not strike down retroactive or prospective legislation unless it proves to be invalid pursuant to a rational basis test. Fearing accusations of judicial activism, the Supreme Court started to bring in precedents allowing for a stricter standard of review under the takings clause. In spite of Penn Central and Lucas' worldwide impact, particularly through investment treaties and investment arbitration, the expansionary trend in takings clause case-law rests upon Nollan/Dolan/Koontz's rough proportionality test, on the one hand, and upon Eastern Enterprises' broad definition of property.

\section{The Protection of Property Rights AND LEGITIMATE EXPECTATIONS UNDER THE EUROPEAN CONVENTION ON HUMAN RightS}

In this part, we will address how the ECtHR has been reading art. 1 of Protocol No. 1 to the ECHR, the provision aimed the protection of

${ }^{71}$ J. L. Kainen, "The historical framework for reviving constitutional protection for property and contract rights", Cornell Law Review, Vol. 79, 1993, p. 93. 
property, frequently invoked in conjunction with art. 6 of the ECHR, which protects the right to a fair trial. ${ }^{72}$

\section{The Structure of Article 1 of Protocol No. 1}

Briefly, in structural terms, art. 1 contains three sentences addressing different types of government interference with property.

The first sentence (Rule 1) holds that "every natural or legal person is entitled to the peaceful enjoyment of its possessions". It serves as a general "catch-all" category for interferences not covered by the remaining sentences. ${ }^{73}$ Rule 1 covers a wide range of situations, such as the refusal of access to land occupied by armed forces, in Loizidou v. Turkey, ${ }^{74}$ regulations on compensation for persons whose property was taken

${ }^{72}$ R. Higgins, "The taking of property by the State: recent developments in International law", Recueil des Cours, Vol. 176, 1992, p. 355; Allen, supra note 1, p. 107; Sochacki, supra note 30, p. 435 et seq.; P. Popelier, "Legitimate expectations and the law maker in the case law of the European Court of Human Rights", European Human Right Law Review, Vol. 1, 2006, p. 10; S. L. Escarcena, "Interferences with property under European Human Rights Law", Florida Journal of International Law, Vol. 24, 2012, p. 513; Perkmans, supra note 52, p. 112; Kriebaum, supra note 4, p. 234; L. Sermet, “La Convention européenne des Droits de l'Homme et le droit de propriété" (The European Convention on Human Rights and the right to property), Dossier sur les Droits de l'Homme, Vol. 11, 1999, p. 11; C. QuézelAmbrunaz, "L'acception européenne du bien en mal de définition", Recueil Dalloz, Vol. 31, 2010, p. 2024; A. R. Çoban, “Inflation and Human Rights: protection of property against inflation under the European Convention on Human Rights", Essex Human Rights Review, Vol. 2, 2005, p. 62; P. Sales, "Property and Human Rights: Protection, expansion and disruption", Judicial Review, Vol. 11, 2006, p. 141; R. Hostiou, "La Cour européenne des Droits de l'Homme et la théorie de l'expropriation indirecte" (The European Court of Human Rights and the theory of indirect expropriation), Rev. trim. dr.h., Vol. 7, 2007, p. 385; M. Sigron, Legitimate expectations under article 1 of Protocol no. 1 to the European Convention on Human Rights, Intersentia, 2014; R. Lang, "Unlocking the First Protocol: Protection of Property and the European Court of Human Rights", Human Rights Law Journal, Vol. 29, 2006, p. 205; S. Drooghenbroeck, "The concept of "possessions" within the meaning of Article 1 of the First Protocol to the European Convention for the Protection of Human Rights and Fundamental Freedoms", The European Legal Forum, Issue 7, 2000, p. 437;

73 Amongst many, Jokela v. Finland, Application no, 28856/95, Judgment of 21.5.2002, para. 49; Back v. Finland, Application no, 37598/97, Judgment of 20.7.2004, para. 58.

${ }^{74}$ Loizidou v. Turkey, Judgment of 18.12.1996, Series A No. 310, para. 63. 
over by virtue of certain statues enacted under the totalitarian regime, in Broniowski v. Poland, ${ }^{75}$ a law prescribing that an arbitration clause contained in a concession contract was no longer valid notwithstanding the fact that the arbitral court had already issued a decision requiring the State to pay compensation, in Stran Greek Refineries v. Greece, ${ }^{76}$ delays in VAT refunding, in Intersplav v. Ukraine, ${ }^{77}$ termination of a lease without prior notice, in Bruncrona v. Finland, ${ }^{78}$ or social allowances and pensions reductions, in Kjartan Ásmundsson v. Iceland. ${ }^{79}$

The second sentence (Rule 2) sets down that "no one shall be deprived of his possessions except in the public interest and subject to the conditions provided by law or by the general principles of international law." It is

75 Broniowski v. Poland, Application no. 31443/96, Judgment of 22.6.2004, para. 136. The end of the communist regime in Eastern Europe led to a sequence of claims, ranging from compensation issues, restitution issues and enforcement of judgments. See, for example, Stefanov v. Bulgaria, Application no. 35399/05, Judgment of 27.10.2015, Stojanovski and others v. TFYR of Macedonia, Application no. 14174/09, Judgment of 23.10.2014, Driza v. Albania, Application no. 33771/02, Judgment of 2.6.2008, Dukic v. Bosnia and Herzegovina, Application no. 4543/09, Judgment of 19.6.2012, Dumbrava v. Romania, Application no. 25234/03, Judgment 17.2.2009, Gjonbocari and others v. Albania, 23.10.2007, no. 10508/02, Hadzhigeorgievi v. Bulgaria, Application no. 41064/05, Judgment of 16.7.2013, Ilieva and others v. Bulgaria, Application no. 17705/05, Judgment of 3.2.2015, J.S and A.S v. Poland, Application no. 40732/98, Judgment of 12.10.2005, Jasiuniené v. Lithuania, Application no. 41510/98, Judgment of 6.6.2003, Karaivanova and Mileva v. Bulgaria, Application no. 35857/05, Judgment of 17.6.2014, Kehaya and others v. Bulgaria, Applications no. 47797/99 and 68698/01, Judgment of 12.1.2006, and Lindner and Hammermayer v. Romania, Application no. 35671/97, Judgment of 3.12.2002.

${ }^{76}$ Stran Greek Refineries v. Greece, Judgment of 9.12.94, Series A No. 301-B, para. 66.

77 Intersplav v. Ukraine, Application no. 803/02, Judgment of 23.5.2007, para. 33. See also Aon Conseil et Courtage S.A and another v. France, Application no. 70160/01, Judgment of 25.1.2007, para. 44; "Bulves" AD v. Bulgaria, Application no. 3991/03, Judgment of 22.4.2009, para. 61.

78 Bruncrona v. Finland, Application no. 41673/98, Judgment of 16.2.2005, para. 79.

79 Kjartan Ásmundsson v. Iceland, Application no. 60669/00, Judgment of 12.10.2004, para. 40. See also Althoff and others v. Germany, Application no. 5631/05, Judgment of 8.3.2012, para. 47, Andrejeva v. Latvia, Application no. 55707/00, Judgment of 18.2.2009, para. 80, and Buczkiewicz v. Poland, Application no. 10446/03, Judgment of 26.2.2008, para. 65, in which, similarly to Sporrong and Lönnroth v. Sweden, Judgment of 23.7.1982, Series A No. 52, the court dealt with a measure that, though leaving intact the applicants' right to use and dispose of their possessions, significantly reduced the practical and effective exercise of that right. 
well-known that the ECtHR has carved out a thoroughly strict concept of what a deprivation of possessions should amount to, thereby restricting the situations that ought to be qualified as de facto expropriations. In fact, cases where a deprivation was not found ${ }^{80}$ unveil that the court opted for a purely legal standard rather than an economic or patrimonial one, which stresses that nothing but definitive and complete deprivations of property amount to a de facto expropriation under the second sentence. ${ }^{81}$ Perhaps more clearly, "as long as the applicants remained free to sell and use their land, no rule 2 deprivations had occurred" ${ }^{82}$

${ }^{80}$ See, for instance, Mellacher et al. v. Austria, Judgment of 19.12.1989, Series A No. 169, para. 44, Stretch v. The United Kingdom, Application no. 44277/98, Judgment of 3.12.2003, para. 36, Hellborg v. Sweden, Application no. 47473/99, Judgment of 28.5.2006, para. 45, and Lindheim and others v. Norway, Applications no. 13221/08 and 2139/10, Judgment of 22.10.2012, para. 78. In the latter decision, when evaluating a regulation that granted lessees the right to claim extension of their lease on the same conditions as previously, the Court admitted that "the low level of annual rents in their case (less than $0.25 \%$ of the plots' alleged market value) and the indefinite duration of the impugned rent limitation interfered to a very significant degree with the enjoyment of their possessions. Notwithstanding, the Court was not persuaded that "the application of section 33 of the Ground Lease Act to them amounted to expropriation or de facto expropriation, or that it meant that all meaningful use had been taken away." (para. 77).

${ }^{81}$ The recognition of de facto expropriations has been scarce and rather incoherent: Papamichalopoulos v. Greece, Judgment of 24.6.1993, Series A No. 260-B, para. 53, Pressos Compania Naviera SA and others v. Belgium, Judgment of 20.11.1995, Series A No. 332, para. 34, Kehaya v. Bulgaria (supra note 75), para. 77, James v. The United Kingdom, Judgment of 21.2.1986, Series A No. 98, para. 38, and Albergas and Arlauskas v. Lithuania, Application no. 17978/05, Judgment of 27.8.2014, para. 55. Yet, in cases dealing with penalties or sanctions, although acknowledging that the government's regulations had fully deprived the owner of its property, the ECtHR did not find a rule 2 deprivation. For instance, in Air Canada v. The United Kingdom, Judgment of 5.5.1995, Series A No. 316-A, concerning the seizure of an aircraft due to the transportation of cannabis, the Court sustained that "the seizure and demand for payment were to be seen as part of the system for the control of the use of an aircraft (...)", meaning that no transfer of ownership has occurred (para. 32). The seizure of goods in the context of criminal proceedings might, however, be examined under Rule 2 (deprivation), particularly if the confiscation is permanent and entails a conclusive transfer of property, as occurred in B. K. M. Lojistik Tasimacilik Ticaret Limited Sirketi v. Slovenia, Application no. 42079/12, Judgment of 17.01.2017, para. 38, and Andonoski v. The Former Yugoslav Republic of Macedonia, Application no. 16225/08, Judgment of 17.09.2015.

82 Allen, supra note 1, p. 113. 
The third sentence (Rule 3) is premised on the view that the social function of property ${ }^{83}$ demands governments to enforce rules "to control the use of property in accordance with the general interest". It includes planning restrictions, like those in Pine Valley Developments v. The United Kingdom ${ }^{84}$ and Hamer v. Belgium, ${ }^{85}$ withdrawal of licences, in Tre Traktorer Aktiebolag v. Sweden ${ }^{86}$ or in Brosset-Triboulet and others v. France, ${ }^{87}$ confiscation of property, in Handyside v. United Kingdom ${ }^{88}$ and Air Canada v. The United Kingdom, ${ }^{89}$ rent controls, extension of the validity of existing leases and temporary suspension of enforcement of court orders, in Immobiliare Saffi v. Italy, ${ }^{90}$ or the slaughter of animals at risk, in Chagnon et Fournier v. France. ${ }^{91}$

As recurrently stressed by the ECtHR, to conform to the requirements of art. 1, the interference must comply with the legality requirement, which will not be addressed in the present work, and with the principle of fair balance, within the terms we will discuss below.

\section{Possessions Under Article 1 of Protocol No. 1}

The ECtHR has evinced its preference for a rather broad concept of "possessions", which encompasses any pecuniary interests that exist or

${ }^{83}$ M. L. Padelletti, La tutela della proprietà nella Convenzione Europea dei Diritti dell'Uomo, Milano: Giuffrè, 2003, p. 13 ["'l'obiettivi limitato di garantire in singolo dalla confisca (...) senza per altro escludere l'esercizio de un potere conformativo della proprietà da parte degli stati, al fine di garantire la funzion soziale"].

${ }^{84}$ Pine Valley Developments $v$. The United Kingdom, Judgment of 29.11.91, Series A No. 222, para. 56.

${ }^{85}$ Hamer v. Belgium, Judgment of 27.11.2007, no. 21861/03, para. 77.

86 Tre Traktorer Aktiebolag v. Sweden, Judgment of 7.7.1987, Series A No. 159, para. 55.

87 Brosset-Triboulet and others v. France, Application no. 34078/02, Judgment of 29.3.2010, para. 83. Related to the withdrawal or rejection of environmental permits, see Fredin v. Sweden, Judgment of 18.2.1990, Series A No. 192, para. 47, and Huoltoasema Matti Éuren Oy and others v. Finland, Application no. 26654/08, Judgment of 19.1.2010, para. 36.

${ }^{88}$ Handyside $v$. The United Kingdom, Judgment of 7.12.76, Series A No. 24, para. 62.

89 Air Canada v. The United Kingdom (supra note 81), para. 34.

${ }^{90}$ Immobiliare Saffi v. Italy, Application no. 22774/93, Judgment of 28.7.1999, para. 46.

${ }^{91}$ Chagnon et Fournier v. France, Applications no. 44174/06 and 44190/06, Judgment of 15.7.2010, para. 36 . 
will very likely exist in an individual's patrimonial sphere. ${ }^{92}$ In addition, it is worth saying that the concept protects not only each specific pecuniary interest or asset, but also an individual's financial condition as a whole. That is why the levying of taxes as well as the imposition of other monetary liabilities constitutes an interference with the right guaranteed in art. 1 of Protocol no. 1, as the court stated in Arnaud and others v. France ${ }^{93}$ or Gáll v. Hungary. ${ }^{94}$ This conclusion draws solely from the judicial reading of the Convention's disposition and it is neither supported nor disturbed by the second paragraph of art. 1, since the right of the state to "secure the payment of taxes" is not the same thing as the imposition of taxes.

As a consequence of this broad scope, the court appraised as protected "possessions" an assortment of tangible assets (physical goods), earned income, such as salaries, allowances, and pensions, ${ }^{95}$ amounts awarded in judicial proceedings ${ }^{96}$ or amounts related to electricity and gas payments, ${ }^{97}$ intellectual property rights, company shares, ${ }^{98}$ foreign currency savings, ${ }^{99}$ fishing rights, pecuniary interests in estates, ${ }^{100}$ and contractual rights to a certain amount. ${ }^{101}$ This list requires some interpretative remarks.

92 Therefore, as Padelletti, supra note 83, p. 42, rightfully points out, the concept of "possessions" bears a similarity to the common law concept of "estate".

93 Arnaud and others v. France, Applications no. 36918/11, 36963/11, 36967/11, 36969/11, 36970/11 and 36971/11, Judgment of 15.1.2015, para. 24.

${ }_{94}$ Gáll v. Hungary, Application no. 49570/11, Judgment of 4.11.2013, para. 55.

${ }_{95}$ Lelas v. Croatia, Application no. 55555/08, Judgment of 20.8.2010, para. 58.

96 Amat-G LTD and Mebaghishvili v. Georgia, Application no. 2507/03, Judgment of 15.2.2006, para. 56, Eydelman and other "Emigrant Pensioners" v. Russia, Applications no. 7119/05, 9992/07, 10359/07, 13476/07, 3565/08, 10628/08, 33904/08, 33918/08, 40058/08, 42112/08, 42115/08 and 60792/08, Judgment of 4.2.2011, para. 32, Khrykin v. Russia, Application no. 33186/08, Judgment of 19.7.2011, para. 54, and Kuzmina v. Russia, Application no. 15242/04, Judgment of 2.7.2009, para. 30.

${ }_{97}$ Budchenko v. Ukraine, Application no. 38677/06, Judgment of 24.4.2014, para. 36.

98 Lekic v. Slovenia, Application no. 36480/07, Judgment of 14.2.2017, para. 69-71.

99 A and B v. Montenegro, Application no. 37571/05, Judgment of 5.3.2013, para. 67; Alisic and others v. TFYR of Macedonia, Application no. 60642/08, Judgment of 16.7.2014, para. 97; Kovacic and others v. Slovenia, Application no. 44574/98, 45133/98 and 48316/99, Judgment of 3.10.2008.

${ }^{100}$ Fokas v. Turkey, Application no. 31206/02, Judgment of 29.12.2009, para. 42; Fabris v. France, Application no. 16574/08, Judgment of 7.2.2013, para. 55.

101 Asito v. Moldova, Application no. 40663/98, Judgment of 8.2.2006, para. 60, and Back v. Finland (supra note 73). 


\section{The Dual Role of Legitimate Expectations Under ARTICLE 1 OF PROTOCOL No. 1}

\subsection{Legitimate Expectations as "Possessions"}

In the light of the ECtHR case law, the concept of legitimate expectations acquires a different meaning depending on the stage of judicial reasoning at which it is applied. Indeed, when the Court seeks to appraise whether a "possession" under art. 1 is at stake, the concept of legitimate expectations bears some resemblance to the Supreme Court's "investment-backed expectations", i.e. to the legal probability of earning a certain amount of money. In this regard, a legitimate expectation is related to possessions not yet in existence and depicts the likelihood of success, under the national law, of claims able to generate a future amount of money.

The expectation of obtaining effective enjoyment of a property right is legitimate provided that it has a sound legal basis under the national legal system and/or under the established case law and refers to property rights, which means that "no such expectation could come into play in the absence of an asset falling within the ambit of article 1 of Protocol No. 1" ${ }^{102}$ The difference between legitimate expectations and "existing" possessions does not concern the underlying types of assets, but is fundamentally a question of degree as to the potency of certainty of these assets. ${ }^{103}$ As the court hold in Draon v. France ${ }^{104}$ in reference to a former decision:

"The legitimate expectation identified in the Pressos Companía Naviera S.A and others case did not in itself constitute a proprietary interest; it related to the way in which the claim qualifying as an asset would be treated under domestic law, and in particular to the reliance on the fact that the established case-law of the national courts would continue to be applied in respect of damage which had already occurred."

102 Kopecky v. Slovakia, Application no. 44912/98, Judgment of 28.9.2004, para. 48.

103 Sochacki, supra note 30, p. 466.

${ }^{104}$ Draon v. France, Application no. 1513/03, Judgment of 6.10.2005, Application no. 1513/03, para. 67. 
In this sense, the detection of a "possession" is premised upon a factual enquiry, which requires the Court to operate a thorough scrutiny of the State party legal system and case law. For instance, in Kopecky v. Slovakia, ${ }^{105}$ a case dealing with a claim for the restitution of coins confiscated during the communist period, the court concluded that the applicant did not have a "possession" under art. 1 of Protocol No. 1, since there were doubts concerning the compliance with statutory conditions for restitution. ${ }^{106}$ Suffice to say that, in establishing these requirements, the court intends to exclude from the chapeau of art. 1 the claims that embody nothing but a mere hope of acquiring a possession. ${ }^{107}$

Even though this is to a large extent a fact-based analysis, the court has a few times engaged in a normative assessment of the domestic case law in order to conclude that the claimant benefited after all from a legitimate expectation, and consequently, a possession under art. 1. The Djidrovski v. The Former Yugoslavian Republic of Macedonia case is a good example of this avenue. It handled the refusal, by Macedonia, ${ }^{108}$ to assume the obligations of the former Yugoslav army, a fact that prevented the claimant - a former officer of the army - from acquiring a socially owned apartment at a beneficial price. In the judgment, the Court advanced that, notwithstanding the domestic court's refusal to uphold the claimant's right, he had a legitimate expectation that the purchase would take place at a reduced price.

${ }^{105}$ Kopecky v. Slovakia (supra note 102), para. 58.

${ }^{106}$ In Lay Lay v. Malta, Application no. 30633/11, Judgment of 23.7.2013, para. 78, and Albu and others v. Romania, Application no. 34796/09 and 63 other cases, Judgment of 10.5.2012, para. 47, for example, the ECtHR has also concluded for lack of a "possession" under article 1 of Protocol No. 1.

107 See, in this sense, Cazacu v. Moldova, 23.10.2007, no. 40117/02, para. 37, "Bulves" AD v. Bulgaria (note 133), para. 53, Van der Mussele v. Belgium, 23.11.1983, no. 8919/89, para. 48, Basarba Ood v. Bulgaria, 7.4.2010, no. 77660/01, para. 40, Beshiri and others v. Albania, 12.2.2007, no. 7352/03, para. 77, Béláné Nagy v. Hungary, 10.2.2015, no. 53080/13, para. 35, Jantnerv. Slovakia, 9.7.2003, no. 39050/97, para. 33, Bellizzi v. Malta, 28.11.2011, no. 46575/09, para. 74, and Ramaer and Van Willigen v. The Netherlands, 23.10.2012, no. 34880/12, para. 80-81.

108 Djidrovski v. TFYR of Macedonia, 24.2.2005, Application no. 46447/99, para. 85. 


\subsubsection{JUdicial Proceedings and the Right to a Fair Trial}

Most often, the Court assesses claims involving non-yet-existing "possessions" under art. 1 of Protocol No. 1 in conjunction or in addition to art. 6 of the Convention, which contains the right to a fair trial. The issue underneath these claims concerns, on the one hand, the influence of legislative or administrative measures on pending judicial proceedings, and, on the other, undue difficulties created by state organs in the enforcement of judicial decisions.

It is worth mentioning that these difficulties can be labelled either as interferences with existing possessions ${ }^{109}$ or as interferences with legitimate expectations, despite the grounds for the distinction not being clearly put forward in the case law. ${ }^{110}$ In fact, whereas in Sierpinski v. Poland, ${ }^{111}$ a case dealing with the annulment of an administrative decision that transferred private property to the municipality during the communist regime, the Court held that a judicial decision awarding a fixed amount of compensation provided the claimant with a "legitimate expectation", in Dementyev v. Russia, ${ }^{112}$ a military court decision awarding a certain amount originating from daily allowances was considered to be a "possession", without any reference being made to legitimate expectations.

The caseload depicts more consistency when approaching legislative and administrative interferences with judicial disputes, aimed at influencing the outcome of judicial proceedings, at preventing proceedings from being open, or at rendering void final and enforceable decisions. Following the leading case Pressos Compania Naviera SA and others v. Belgium, ${ }^{113}$ the Court has on many occasions stated that interferences

109 Kehaya and others v. Bulgaria (supra note 75), para. 72.

110 See, among others, Dementyev v. Russia, Application no. 3244/04, Judgment of 6.2.2009, para. 31, Bodrov v. Russia, Application no. 17472/04, Judgment of 12.2.2009, para. 26, Agasaryan v. Russia, Application no. 39897/02, Judgment of 20.2.2009, para. 31, and Ambruosi v. Italy, Application no. 31227/96, Judgment of 19.1.2001.

111 Sierpinski v. Poland, Application no. 38016/07, Judgment of 3.2.2010, para. 66.

112 Dementyev v. Russia (supra note 110), para. 31.

113 Pressos Compania Naviera SA and others v. Belgium (supra note 81). 
of the legislature with the administration of justice demand, under art. 6 of the Convention, a higher threshold of justification, namely "compelling grounds of the general interest". ${ }^{114}$ Therefore, the contracting state's margin of appreciation under article 6 is substantially lower than under art. 1 of Protocol No. 1. In Maggio and others v. Italy, ${ }^{115}$ a case about an interpretative law on old-age pensions regulation, which influenced the outcome of pending litigation, the Court repudiated the financial arguments advanced by the Italian government thereby finding a violation of art. 6 of the Convention. At the same time, however, it ruled out a violation of art. 1, in view of the fact that the measure had not impaired the essence of the claimant's pension rights and that it was intended to restore equality and avoid unjustified advantages. ${ }^{116}$

But legitimate expectations can also surface irrespective of any connection with judicial proceedings. In our view, three additional sources of legitimate expectations are discernible in the ECtHR's caseload.

\subsubsection{Pensions and Social Allowances}

The first is related to pensions and social allowances in general. ${ }^{117}$ The Court has put forward a considerably solid set of principles in this regard, which emphasize that, although the ECHR does not guarantee the right

114 See, among many others, Smokovitis and others v. Greece, Application no. 46356/99, Judgment of 11.7.2002, para. 23, Gorraiz Lizarraga and others v. Spain, Application no. 62543/00, Judgment of 10.11.2004, para. 64, Azienda Agricola Silverfunghi, A.A.S and others v. Italy, Application nos. 48357/07, 52677/07, 52687/07 and 52701/07, Judgment of 24.9.2014, para. 76, Agrati and others v. Italy, Application no. 43549/08, 6107/09 and 5087/09, Judgment of 28.11.2011, para. 58, Maggio and others v. Italy, Application no. 46286/09, $52851 / 08,53727 / 08,54486 / 08$ and 56001/08, Judgment of 31.5.2011, para. 43, Stefanetti and others v. Italy, Application no. 21838/10, 21849/10, 21852/10, 21855/10, 21860/10, $21863 / 10,21869 / 10$ and 21870/10, Judgment of 15.4.2014, para. 38. We refer only to cases where the court has assessed governmental measures under art. 6 of the Convention and art. 1 of Protocol No. 1, separately or in conjunction.

115 Maggio and others v. Italy (supra note 114).

116 See, by contrast, Stefanetti v. Italy (supra note 114), para. 66.

117 On the issue, see I. Leijten, "Social security as a Human Rights issue in Europe", ZaöRV, Vol. 2013, p. 177; T. Novitz, "Labour rights and property rights: implications for (and beyond) redundancy payments and pensions?", Industry Law Journal, Vol. 41, 
to pension or to any social benefit, once the contracting State enacts legislation introducing any form of social security scheme, this must be regarded as generating a proprietary interest for persons satisfying the administrative requirements. ${ }^{118}$

Hence, the ECtHR has overtly recognized that legislative amendments that, by setting different criteria of eligibility or reducing the level of benefits, affect the predictable and legitimate possibility of earning a certain amount of money should be treated as interferences with "possessions" under art. 1 of Protocol No. 1. ${ }^{119}$ Indeed, in Béláné Nagy v. Hungary, ${ }^{120}$ a case dealing with the termination of the applicant's disability pension by virtue of a legislative amendment that changed the criteria on disability levels, the Court explained its reasoning in the following terms:

"In these circumstances, the Court is satisfied that, once meeting the administrative requirements of the disability pension scheme as in force at the first material point in time (that is, in 2001), the applicant obtained, for the purposes of art. 1 of Protocol No. 1, a formal recognition of her legitimate expectation to receive a disability pension/allowance as and when her medical condition would so necessitate."

Moreover, the Court has abandoned the distinction between contributory and non-contributory benefits for the purpose of applying art. 1 of Protocol No. 1, ${ }^{121}$ which means that the reduction of any of

2012, p. 136; A. Tsetoura, "Property protection as a limit to deteriorating social security protection", European Journal of Social Security, Vol. 15, 2013, p. 55.

118 See, in this regard, Béláné Nagy v. Hungary (supra note 106), para. 35, Klein v. Austria, Application no. 57028/00, Judgment of 3.3.2011, para. 42, Koufaki and Adedy v. Greece, Application no. 57665/12 and 57657/12, Judgment of 7.5.2013, para. 23, Budchenko v. Ukraine (supra note 97), para. 36, B. v. The United Kingdom, Application no. 36571/06, Judgment of 14.2.2012, para. 36.

119 Béláné Nagy v. Hungary (supra note 106), para. 38; Banfield v. The United Kingdom, Application no. 6223/04, Judgment of 18.10.2005, para. 10; Stefanetti v. Italy (supra note 114), para. 50; Kjartan Ásmundsson v. Iceland (supra note 79), para. 44; Klein v. Austria (supra note 118), para. 45.

120 Béláné Nagy v. Hungary (supra note 106), para. 47. The case was referred to the Grand Chamber, that upheld the decision of the Chamber [Bélané Nagy, Application no. 53080/13, Judgment of 13.12.2016].

${ }^{121}$ Stec and others $v$. The United Kingdom, Application no. 65731/01 and 65900/01, Judgment of 12.4.2006, and Béláné Nagy v. Hungary (supra note 106), para. 48, B. v. The United Kingdom (supra note 118), para. 36, and Andrejeva v. Latvia (supra note 74), para. 76. 
these benefits could be envisaged as an interference with "possessions". However, the distinction previously upheld by the Court remains significant insofar as the issue is to evaluate whether the applicant was called to bear an excessive and disproportionate burden. ${ }^{122}$

Finally, upcoming social security benefits that are contingent on the information presented by the recipients only amount to possessions protected under art. 1 provided that the beneficiaries are in good faith. ${ }^{123}$ This principle emerges with clarity from two rather similar cases - Moskal v. Poland, ${ }^{124}$ on the one hand, and B.v. The United Kingdom, ${ }^{125}$ on the other.

The first case concerned the withdrawal of an early-retirement pension for persons raising children requiring constant care. The pension was issued based on a medical report that certified that the applicant's son suffered from a pulmonary disease that demanded constant assistance by his mother. One year later, the social security authority cast doubts upon the accuracy of the medical certificate and, in consequence, discontinued the payment of the pension. In view of the factual record, the Court acknowledged that the applicant had applied for the early retirement pension "in good faith and in compliance with the applicable law", and that she was justified in thinking that "unless there was a change in the condition of her child's health the decision would not lose its validity". ${ }^{126}$ Accordingly, the applicant was found to have a substantive interest protected by art. 1 of Protocol No. 1.

The second case relates to the discontinuance of a non-contributory personal allowance that was conferred upon the applicant based on her income and children. The applicant failed to notify the authorities that her children had been taken into care and that she had ceased to meet the conditions for receiving the allowance. Insofar as the recovery of overpaid benefit was concerned, the Court refused to acknowledge that the applicant had a proprietary interest under art. 1, because "to hold

122 Béláné Nagy v. Hungary (supra note 106), para. 48; Stefanetti and others v. Italy (supra note 114), para. 63.

${ }^{123}$ B. v. The United Kingdom (supra note 118), para. 39.

${ }^{124}$ Moskal v. Poland, Application no. 10373/05, Judgment of 15.9.2009.

125 B. v. The United Kingdom (supra note 118).

${ }^{126}$ Moskal v. Poland (supra note 124), para. 44. 
otherwise would enable recipients of benefits to profit from their own omissions and in some cases fraud."127

\subsubsection{The Passage of Time in the Face of InValid or Precarious Administrative Action}

Legitimate expectations can also originate from a situation where a state authority has issued a non-valid or precarious act which, by the lack of diligence of administrative bodies or by the time elapsed since its issuance, has given rise to the conviction that a beneficial patrimonial position would not be interrupted.

This is rather frequent in cases dealing with private occupation of public property, such as coastal houses, dykes, and berths. For instance, in Brosset-Triboulet and others v. France, ${ }^{128}$ the Court handled the refusal, by the French authorities, to renew an authorization to occupy a deck and a house located on public land. It is worth mentioning that the authorization was precarious - it should not have lasted longer than 1990 and expressly contained an obligation to restore the site to its original state once revoked. Nevertheless, the Court advanced that "the time that elapsed had the effect of vesting in the applicants a proprietary interest in the peaceful enjoyment of the house that was sufficiently established and weighty to amount to a "possession" (...)" ${ }^{129}$

Besides, there are a few cases where the Court accepted the existence of legitimate expectation under art. 1 despite the fact that the building permit issued by the planning authorities was invalid, as in Pine Valley v. Ireland ${ }^{130}$ or that the building was erected without a planning permission,

127 B. v. United Kingdom (supra note 118), paras 39-40.

128 Brosset-Triboulet and others v. France (supra note 87). See, similarly, Depalle v. France, Application no. 34044/02, Judgment of 29.3.2010, and Bellizzi v. Malta (supra note 107).

129 Brosset-Triboulet and others v. France (supra note 87), para. 71 (emphasis added).

130 Pine Valley Developments v. The United Kingdom (supra note 84). The applicant bought some acres of land in reliance of an outline planning permission that contravened the development plan. In consequence, the Supreme Court held that the permission had been ultra vires and was therefore a nullity. The Court highlighted that until the issuance of such decision, "the applicants had at least a legitimate expectation of being able to carry on their proposed development" (para. 51). 
as in Hamer v. Belgium. ${ }^{131}$ In the latter, the Court pointed out that, given the time elapsed since the construction (27 years) and considering that the applicant had paid taxes on the building, her proprietary interest in the enjoyment of her holiday home had given rise to a legitimate expectation of being able to continue to enjoy that possession.

Finally, situations in which there is a crucial connection between a notyet passed government's act and a "possession" held by the applicant ${ }^{132}$ should also deserve close attention. The best example is Centro Europa v. Italy. ${ }^{133}$ Indeed, the applicant was granted, in 1999, a licence for nationwide terrestrial television broadcasting, in virtue of which it was entitled to three frequencies. Given that the plan that would have allowed the allocation of frequencies was never implemented, the applicant was unable to broadcast until 2009. The Court emphasized the fact that, without the allocation of broadcasting frequencies, the licence to broadcast was "deprived of its substance", and that the applicant held a legitimate expectation of being granted those frequencies.

\subsection{Legitimate Expectations as a Component of "FaIR BALANCE"}

The concept of legitimate expectations, in parallel with other components of the rule of law principle, is constantly convened at the balancing stage, that is to say after a "possession" under art. 1 of Protocol No. 1 has been found. ${ }^{134}$ It is fair to say that, at the balancing stage, the Court pays special attention to both objective and subjective dimensions of legitimate expectations.

It envisages the concept in rather objective terms, ${ }^{135}$ as a component of the rule of law, which demands that public powers act consistently

${ }^{131}$ Hamer v. Belgium (supra note 85), para. 76.

${ }^{132}$ Popelier, supra note 72, p. 15.

133 Centro Europa 7 S.R.L and Di Stefano v. Italy, Application no. 38433/09, Judgment of 7.6.2012. See also Stretch v. The United Kingdom (supra note 80).

${ }^{134}$ Perkmans, supra note 52, p. 119.

${ }_{135}$ M. Paparinskis, The International Minimum Standard and Fair and Equitable Treatment, Oxford, 2013, p. 235; Popelier, supra note 72, p. 10. 
and transparently, according to the principles of good governance, ${ }^{136}$ legal certainty, ${ }^{137}$ respect for acquired rights, ${ }^{138}$ and foreseeability as encompassing a duty to pass transitional relief measures. ${ }^{139}$

The principle of good governance draws on the assumption that public authorities must act in good time and in an appropriate and consistent manner in correcting their mistakes. In Peter Matas v. Croatia, assessing a situation where a commercial building was estimated to have cultural heritage value and, therefore, was submitted to preventive protection during several years, the Chamber remembered that, under the principle of good governance, public authorities should have conducted measurements, assessments or studies in order to estimate the applicant's building cultural heritage value in good time.

The Court has scarcely ever admitted a violation of art. 1 solely on the basis of the public powers' inconsistent or unscrupulous conduct, i.e. irrespective of the predictability and of the impact of the measure on the applicant's patrimonial sphere. ${ }^{140}$ It is clear-cut, though, that the Court is inclined to rule against governmental measures that fail to meet those standards even if the applicant's conduct lacks due diligence, a feature that evidences that the ECtHR standard is considerably more objective than, for instance, that of the US Supreme Court or of the European Court of Justice.

136 See Moskal v. Poland (supra note 124), para. 72, Digryté Klibaviciené v. Lithuania, Application no. 34911/06, Judgment of 21.10.2014, para. 33, Lelas v. Croatia (supra note 95), para. 74, and Jokela v. Finland (supra note 73), para. 65; Kalev v. Bulgaria, Application no. 9464/11, Judgment 10.11.16, para. 27, Kryvenkyy v. Ukraine, Application no. 43768/07, Judgment of 16.2.2017, para. 45.

137 See, among others, Kehaya v. Bulgaria (supra note 75), para. 76, Decheva and others v. Bulgaria, Application no. 43071/06, Judgment of 26.9.2012, para. 57, and Solomun v. Croatia, Application no. 679/11, Judgment of 2.7.2015, para. 52; Stamova v. Bulgaria, Application no. 8725/07, Judgment of 19.1.2017, para. 70, Rusu Lintax Srl. v. The Republic of Moldova, Application no. 17992/09, Judgment of 13.12.2016, para. 13.

138 See Béláné Nagy v. Hungary (supra note 106), para. 53; Jakeljic v. Croatia, Application no. 22768/12, Judgment of 28.6.2016, para. 45.

${ }^{139}$ Lekic v. Slovenia (supra note 98), para. 122.

140 Padelletti, supra note 83 , p. 84, seems to go even further by suggesting that the case law confers the highest significance to the public powers' behaviour, independently of the applicant's good faith and respect for the national legal system. 
In Lelas $v$. Croatia, ${ }^{141}$ the Court conceded that the applicant could legitimately rely on the statements made by public officials "who appear to have the requisite authority to do so". In Jokela $v$. Finland, ${ }^{142}$ the decisive consideration for finding a violation of art. 1 was neither the expropriation nor the inheritance tax, but the combined effect of both measures in the light of the lack of consistency depicted by public authorities. In fact, the market value fixed for the levying of inheritance tax was assessed to be four times higher per square metre than the market value applied in the expropriation proceedings.

A very recent case, Werra Naturstein v. Germany, ${ }^{143}$ clearly evinces that public authorities' conduct creates expectations even when the legal system openly enables interferences with the applicant's investment. In short, the applicant was given a licence to quarry a limestone deposit for 25 years at a time when the building of a motorway across the quarry was already being planned. Consequently, the applicant had to stop quarrying limestone and transferred its activities to a nearby mining site. He received compensation for the plot of land occupied by the motorway, but there was no formal expropriation of the mining licence. The court underlined that neither the mining authority nor the company could have reasonably been unaware of the planned motorway and of its priority over mining operations. However, the fact that the mining authority issued a licence during a period of uncertainty as to the exact location of the motorway indicated that a total lack of compensation was not justified.

Foreseeability also plays a role in determining whether a fair balance was struck. It has been envisioned as a component of the lawfulness of the interference, by imposing the duty to enact transitional relief measures. In a recent case, Lekic $v$. Slovenia, the court held that the principle of lawfulness presupposes that the provisions of domestic law are "foreseeable in their application". Changing the rules of insolvency procedures, by allowing insolvent or inactive companies to be struck off from the court register without winding up, requires that inactive

${ }^{141}$ Lelas v. Croatia (supra note 95), para. 74.

142 Jokela $v$. Finland (supra note 73), paras 61-65.

${ }^{143}$ Werra Naturstein v. Germany, Application no. 31377/12, Judgment of 19.1.2017, paras 50-52. 
and insolvent companies are provided with "sufficient time to institute appropriate proceedings". ${ }^{144}$

On the other hand, several subjective features also come across in the case law. Indeed, special attention is given to the ideas of irreversibility, detrimental reliance, and the validity or legitimacy of expectations. ${ }^{145}$ The focal point is to know whether the applicants would have engaged in the same course of action or inaction if they had predicted the upcoming governmental changes detrimental to them. This is particularly relevant regarding pensions and social allowances. In the abovementioned Moskal v. Poland, ${ }^{146}$ the Court attached significant importance to the fact that, by resigning from her job in order to start receiving the pension, the applicant engaged in an irreversible and decisive course of action. Similarly, in Lakicevic and others v. Montenegro and Serbia, ${ }^{147}$ the Chamber took into consideration the fact that the pension system had encouraged pensioners to reopen their activities on a part-time basis whilst allowing them to continue receiving their pension in full.

An opposite conclusion was reached in Azienda Agricola Silverfunghi A.A.S and others v. Italy, ${ }^{148}$ a case dealing with an authentic interpretation issued by the Italian authorities, which affected pending disputes concerning the accumulation of financial benefits in the agricultural sector. Here, the Court softened the relevance of the accumulation of benefits for the undertaken activities, considering that the applicants "were clearly not in a position whereby they could not run their businesses because of the respective financial burdens."

The validity or legitimacy of expectations is also an important component of the balancing exercise. It is concerned not only with the probability of legal change in times of political uncertainty, but also with the well-founded nature of those expectations in the light of the

${ }^{144}$ Lekic v. Slovenia (supra note 98), para. 91; Lakicevic and others v. Montenegro and Serbia, Application no. 27458/06, 37205/06, 37207/06 and 33604/07, Judgment of 13.12.2011, para. 72.

145 See also Stefanetti and others $v$. Italy (supra note 114), para. 65 ["the applicants made a conscious decision to move back to Italy at a time when they had legitimate expectations of receiving higher pensions and therefore a more comfortable standard of living"'].

${ }^{146}$ Moskal v. Poland (supra note 124).

147 Lakicevic and others v. Montenegro and Serbia (supra note 144), para. 69.

148 Azienda Agricola Silverfunghi, A.A.S and others v. Italy (supra note 114), para. 106. 
substantive structure and values of the legal system. Both features were crucial in Jahn and Others v. Germany. The case focused on the Federal Republic of Germany's Second Property Act, according to which land acquired under former German Democratic Republic's Modrow Law should be reassigned to the public without the payment of compensation. The Modrow Law, it is worth mentioning, had lifted all restrictions on the disposal of land acquired under the land reform, whereupon those in possession of the land became its legitimate owners. The Grand Chamber's reasoning was largely premised on the assumption that Germany, by reasons of social justice, had a duty to correct the heirs' windfall gains under the loophole created by the Modrow Law. ${ }^{149}$

The same reasoning has been applied in a context of financial uncertainty and distress as the one recently experienced in Greece. In Mamatas et autres $v$. Grèce, the court scrutinized the validity of some legislative measure concerning the Greek public debt, namely the collective action clauses, which forced bond holders to participate in an exchange of titles as long as at least two thirds of them agreed to it. The court followed the reasoning taken by the ECJ in a similar case, by stating that, given the speculative nature of the applicants' investments, they should have been aware of the risks involving the debt purchased.

The previous analysis has displayed that, contrary to what to some extent occurs under the ECJ ${ }^{150}$ and the US Supreme Court, the subjective features of legitimate expectations do not always play a decisive role in determining whether a fair balance was struck. As a result, compensation might be paid even if the claimant, owing to his experience and knowhow, ought to have been able to anticipate the interference with its

149 Jahn and others v. Germany, Application no. 46720/99, 72203/01, 72552/01, Judgment of 30.6.2005, para. 116. U. Deutsch, “Expropriation without compensation - the European Court of Human Rights sanctions German Legislation expropriating the Heirs of "New Farmers", German Law Journal, Vol. 6, 2005, p. 1367.

150 D. Galetta, "Legittimo affidamento e leggi finanziarie, alla luce dell'esperienza comparata e comunitaria: riflessioni critiche e proposte per un nuovo approcio in materia di tutela del legittimo affidamento nei confronti dell'attività del legislatore" (Legitimate expectations and budgetary laws in the light of comparative and European Union Law: critical remarks and proposals for a new approach concerning legitimate expectations in legislative activity), Foro Amministrativo: TAR, 2008, p. 1917; Paparinskis, supra note 135, p. 230. 
possessions. Legal scholars have suggested that this difference is due to the margin of appreciation doctrine, i.e. due to the ECtHR's refusal to double check member states' policies especially, though not exclusively, in social policy matters and in times of political or economic distress. ${ }^{151}$ The argument is that, while public authorities are afforded broad discretion in substantive issues, they must at least comply with some rather objective requirements such as good governance, non-retroactivity, or the enactment of transitional relief measures.

To grasp the significance and justification of the margin of appreciation doctrine ${ }^{152}$ within ECtHR jurisprudence would seriously expand the scope of the present work. Notwithstanding, it is worth noting that the standard of review employed by the court varies according to the allegedly violated provisions of the ECHR. For instance, salary and pension cuts receive considerably different treatment depending on whether there is an interference with possessions, under art. 1 of Protocol no. 1, and/or an interference with the right to fair trial enshrined in art. 6 .

Under the former, the court weights a considerable number of factors in order to assess whether a fair balance was struck. It examines the amount or percentage of the reduction, the enactment of transition

151 Paparinskis, supra note 135, p. 237; R. Ergec, “Taxation and property rights under the European Convention on Human Rights", Intertax, Vol. 39, 2011, p. 2 ["the more the court feels constrained to rely on the appreciation of national authorities on complex issues, the greater the temptation to check if at least these authorities reached their decision through a fair and contradictory procedure curbing the risk of arbitrariness to a minimum"].

${ }^{152}$ Among many others, D. L. Donoho, "Autonomy and the margin of appreciation: developing a jurisprudence of diversity within universal Human Rights", Emory International Law Review, Vol. 15, 2001, p. 391; G. Letsas, "Two concepts of the margin of appreciation", Oxford Journal of Legal Studies, Vol. 26, 2006, p. 705; J. Gerards, "Pluralism, deference and the margin of appreciation doctrine", European Law Journal, Vol. 17, 2011, p. 80; A. McHarg, "Reconciling Human Rights and the Public Interest: Conceptual Problems and Doctrinal Uncertainty in the Jurisprudence of the European Court of Human Rights", Modern Law Review, Vol. 62, 1999, p. 671; S. Greer, “The margin of appreciation: interpretation and discretion under the European Convention on Human Rights", Human Rights Files, Vol. 17, 2000; E. Benvenisti, "Margin of appreciation, consensus and universal standards", N.Y.U. J. Int'l L. E Pol., Vol. 31, 1998, p. 843; J. A. Brauch, “The margin of appreciation and the jurisprudence of the European Court of Human Rights: threat to the rule of law", Columbia Journal of European Law, Vol. 11, 2005, p. 113. 
relief measures, the discriminatory character of the interference, and the temporary/definitive character of the measures. ${ }^{153}$ Provided that the essence of the right is not impaired, the court is able to accept the legislator's justifications concerning its course of action as being within the State's margin of appreciation when regulating social policy issues. In Maggio and Others, the ECtHR underlined that the pension reduction "only had the effect of equalizing a state of affairs and avoid unjustified advantages". Similarly, in Da Januário Conceição v. Portugal and Da Silva Carvalho v. Portugal, owing to the exceptional economic and financial crisis and to the insufficiency of previous measures, the court refused to decide whether better alternative measures could have been envisaged in order to reduce the state budget deficit. ${ }^{154}$

However, the same kind of justifications are afforded considerably less weight when the issue is the temporal scope of application of retrospective legislation interfering with pending or upcoming judicial disputes. In Maggio and Others, the court was not persuaded that equalizing a state of affairs and avoiding unjustified advantages were compelling enough to justify a retrospective application of the law. More generally, as stated in Azienda Agricola Silverfunghi A.A.S and others v. Italy, ${ }^{155}$ "financial considerations cannot by themselves warrant the legislature substituting itself for the courts in order to settle disputes". ${ }^{156}$

\subsection{Conclusions on the Dual Role of Legitimate Expectations}

The distinction between legitimate expectations as "possessions" and legitimate expectation as "a component of fair balance" is overly formal. It is true that, when brought forth at the balancing stage, the "legitimacy"

${ }^{153} \mathrm{Da}$ Conceição Mateus and Santos Januário v. Portugal, Application no. 62235/12 and 57725/12, Judgment of 8.10.2013, para. 25-28; Koufaki and Adedy v. Greece (supra note 118), para. 31; Da Silva Carvalho Rico v. Portugal, Application no. 13341/14, Judgment of 24.09.15, para. 45; Mamatas et autres v. Grèce, Application no. 63066/14, 64297/14, 66106/14, Judgment of 30.01.2017, para. 117; Bélané Nagy v. Hungary (supra note 106), para. 117, Kjartan Ásmundsson (supra note 79), para. 43.

${ }^{154} \mathrm{Da}$ Conceição Mateus and Santos Januário v. Portugal (supra note 153), para. 28.

155 Azienda Agricola Silverfunghi, A.A.S and others v. Italy (supra note 114), para. 82.

156 Popelier, supra note 72, p. 17. 
of the expectations acquires a different meaning. It signals no longer the likelihood of gaining money, but rather the unpredictability of a governmental change which is detrimental to the applicant's patrimonial sphere. ${ }^{157}$

As Allen puts it, ${ }^{158}$ the strength and legitimacy of these possessions are highly irregular, which might have some impact on the fair balance test. Similarly, we argue that holding a legitimate expectation as a possession does not always amount to holding a legitimate expectation under the balancing stage. Some cases suggest that the likelihood of obtaining a certain possession uncovers the pathway that the state organs are expected to pursue, thereby highlighting that holding a non-yet-existing possession pursuant to art. 1 empowers the applicant with a legitimate expectation of stability at the fair balance stage. That is why very often the Court undertakes balancing operations at the first stage of the analysis. ${ }^{159}$ However, some of the elements considered at the balancing stage, such as the legitimacy of the expectations, evince that the connection between the two stages of analysis is not always automatic and that reasonable interruptions may occur.

\section{SUmmary OF PARTY II}

Part II started with a description of the structure of art. 1 of Protocol no. 1. It comprises three different rules - peaceful enjoyment of possessions, deprivation of possessions, and control of the use of property - which give the provision enough flexibility to deal in an appropriate manner with all types of interferences with property rights. Our argument is that legitimate expectations play a dual role within the structure of art. 1, as they work both as "possessions" and as an element to which should be given consideration at the balancing stage.

157 See, for example, Kjartan Ásmundsson v. Iceland (supra note 79), para. 44, Huoltoasema Matti Éuren Oy and others v. Finland (supra note 87), para. 39, Digryté Klibaviciené v. Lithuania (supra note 136), para. 36, and Lindheim and others v. Norway (supra note 80), para. 133.

158 Allen, supra note 1, p. 57.

159 Gáll v. Hungary (supra note 94), paras 36-40; Kjartan Ásmundsson v. Iceland (supra note 79), para. 44 . 
As possessions, legitimate expectations bear some resemblance to the Supreme Court's investment-backed expectations, since they indicate the likelihood of gaining money in view of the compliance with the requirements established in each legal system. These criteria have been confirmed in Kopecky v. Slovakia and are now firmly rooted in ECtHR case-law. We suggest that legitimate expectations originate from pending judicial proceedings, pensions, and social allowances, the passage of time regarding precarious or invalid administrative action, and, lastly, from situations where the applicant's existing possession calls for an act by the government without which he would not have acquired that possession at all.

At the balancing stage, and taken in broad terms, legitimate expectations refer to the unpredictability of the governmental interference with possessions. In our view, this unpredictability may come out from both objective and subjective elements. The argument is that the ECtHR's approach towards stability puts considerable weight on the public authorities' behaviour in order to overcome the leniency of the margin of appreciation doctrine.

We conclude that, despite the different meaning attached to "legitimacy" in each of the stages of reasoning, there is some connection between expectations as possessions and expectations as an element of fair balance.

\section{Comparative Remarks}

After carefully analysing how both systems address the same constitutional issue - the protection of property rights and patrimonial expectations in view of a legal change - we consider that we are ready to propose some comparative remarks, aimed at unveiling the main similarities and differences between the two systems.

\section{SCope and Interferences With Property RightS}

Both systems accept a broad definition of property rights in terms of including specific legal rights with economic value. The definition 
encompasses monetary interests, even if they do not arise out of a specific and identifiable fund of money. The ECtHR has consistently held that taxation is in principle an interference with the right guaranteed by the first paragraph of art. 1 of Protocol no. 1, "since it deprives the person concerned of a possession, namely the amount of money which must be paid". ${ }^{160}$

Whereas the Supreme Court reviews taxation, namely retroactive taxation, under the due process of law clause, as we made clear from United States v. Carlton, the imposition of general financial liabilities has been considered, since Eastern Enterprises, as an interference with property rights which might be protected under the Fifth amendment. In his dissenting opinion, Justice Breyer highlighted that the takings clause can apply to monetary interests provided that these interests arise out a "specific fund of money". Other legal scholars seem to agree with him, raising the question of how to distinguish, after Eastern, the obligation to pay taxes from the obligation to pay money under a financial responsibility. ${ }^{161}$

No similar objections were raised under art. 1 of Protocol no. 1. This is owing to the different impact of the qualification. Within the human rights system, the imposition of financial liabilities or the levying of taxes will most certainly be reviewed pursuant to rules 1 or 3 of art. 1, the objective being to decide whether such interference manages to strike a fair balance. Different conclusions will arguably be reached under the Supreme Court's all or nothing approach to the takings clause. At least one of the Penn Central's tests will receive a straightforward answer: the economic impact is substantial because the company is deprived of the amounts it must pay to comply with the financial obligation. ${ }^{162}$

It would be unfair to suggest that these issues did not exist prior to Eastern. As we pointed out in Part I, with regard to the takings clause, jurisprudence has sought to draw a distinction between (regulatory) takings and restraints on the use of property tantamount to public

160 Burden v. The United Kingdom, Application no. 13378/05, Judgment of 29.4.1998, para. 59; Imbert de Tremiolles c. France, Application no. 2583405 and 27815/05, Judgment of 4.1.2008.

161 Krotoszynski, supra note 11, p. 729.

162 Eastern Enterprises v. Apfel (supra note 56). 
nuisances. Under the ECHR, a similar distinction exists between deprivation of possessions and regulations controlling the use of property. However, there are at least two major dissimilarities among these systems.

First, under the ECtHR's approach, the duty to compensate is not contingent on the label given to the interference. As M. Perkmans rightly asserted, "the characterization of a measure as a regulation does not per se exclude a right to compensation for the owner" ${ }^{163}$ For instance, whereas in Miller v. Schoene, ${ }^{164}$ the Supreme Court empowered the government to cut unhealthy trees without paying compensation to the owner, in Chagnon et Fournier $v$. France, ${ }^{165}$ analysing the killing of animals for disease control purposes, the ECtHR gave due consideration to the compensation paid to the applicant as an element evidencing that a fair balance between the interests at stake had been achieved.

Second, no categorical takings rule exists under art. 1 of Protocol No. 1. Although it is possible to find a deprivation (Rule 2) before the balancing stage, the economic impact of the measure on the investor's possessions is never enough to trigger the duty to compensate. Jahn and others v. Germany is a good example of the latter assertion. ${ }^{166}$

Thus, despite the shared intention of using the guarantee of property as a due process of law functional equivalent, it is self-evident that the current judicial interpretation of art. 1 (P1) makes it a rather more appropriate tool to use as a general standard of fairness than the Supreme Court's on-going reading of the Fifth amendment. Though both dispositions are being interpreted as a guarantee against governmental action having a direct or indirect impact on patrimonial rights, ${ }^{167}$ only the latter has the structure to fulfil that function in a coherent manner.

Finally, the flexibility of the scheme brought about by the ECtHR allows it to overcome the difficulties of identifying the claims of the second rule. ${ }^{168}$ This is not to say, however, that the classification carried by the court is void of material consequences regarding the validity of

${ }^{163}$ Perkmans, supra note 52 at p. 118.

${ }^{164}$ Miller v. Schoene (supra note 42).

165 Chagnon et Fournier v. France (supra note 91), para. 57.

166 Jahn and others v. Germany (supra note 149), para. 117.

167 Allen, supra note 1, p. 282.

168 Paparinskis, supra note 135, p. 179 and 234. See, in the case law, Stretch $v$. The United Kingdom (supra note 80), para. 36. 
the measure. Effectively, when the court finds that a measure amounts to a deprivation - something that rarely occurs ${ }^{169}$ - the validity of the measure will most probably be contingent on the payment of compensation so that the fair balance of the governmental course of action can be preserved. ${ }^{170}$

\section{INVESTMENT-BACKED EXPECTATIONS AND LEGITIMATE EXPECTATIONS}

The ECtHR's approach vis-à-vis legitimate expectations holds some similarities to the Supreme Court's investment-backed expectations.

In fact, both concepts hinge on the same idea, i.e., the legal probability of income coupled with the assumption that the mere hope of acquiring money does not reserve protection. However, Sochacki's ${ }^{171}$ observation that, as opposed to the Supreme Court, the ECtHR honours "significantly less vested, or even completely unvested, expectations" is also accurate. For example, the speculative or undue expectations of profit upheld as a "possession" in National \& Provincial Building Society v. The United Kingdom ${ }^{172}$ were rejected as "investment-backed expectations" in Guggenheim v. City of Goleta. ${ }^{173}$ There are structural reasons for this tenet. Whereas under the ECtHR's standpoint the existence of a "possession" is merely an admissibility issue, under the Supreme Court's reasoning the recognition of an investment-backed expectation is a decisive step within the process of recognizing the occurrence of a taking.

169 Paparinskis, supra note 135, p. 234; Padelletti, supra note 83; Allen, supra note 1; Escarcena, supra note 72 at p. 522. As opposed to the Supreme Court caseload, the refusal to grant building permits is not a de facto expropriation, but a control of use of property, as stated by the ECtHR in Fredin v. Sweden (supra note 87), para. 47, or Hellborg v. Sweden (supra note 80 ), para. 45 .

170 Brosset-Triboulet and others v. France (supra note 87), para. 94, Bruncrona v. Finland (supra note 78), para. 68, Draon v. France (supra note 104), para. 79, N.A and others. v. Turkey, Application no. 37451/97, Judgment of 11.10.2005, para. 41.

171 Sochacki, supra note 30, p. 464.

172 National \& Provincial Building Society, The Leeds Permanent Building Society and the Yorkshire Building Society v. The United Kingdom, Application no. 21319/93, 21449/93 and 21675/93, Judgment of 23.10.1997, para. 70.

173 Guggenheim v. City of Goleta (supra note 42). 
Expectations play a major role in evaluating the validity of pension reductions and public employees' salary cuts. Under the contract clause, they evince the substantiality of the impairment of public contracts. Under art. 1 of Protocol no. 1, they help to establish whether the government's interference struck a fair balance between the interests at stake. Interestingly, the factors considered in the weighting phase reveal considerable similarities. Both systems emphasize the irreversibility of the choices made by those already retired, the importance of transition relief periods and the contextual predictability of the normative change.

In Allied Structural Steel, a case dealing with the impairment of a private pension fund, ${ }^{174}$ the Supreme Court emphasized that the legislature could not change the company's obligations in an area where "the element of reliance was vital" and without approving "any provision for gradual applicability or grace periods". Moreover, US courts have developed the highly-regulated industry exception, ${ }^{175}$ according to which legislative changes are more likely to occur when the area covered by the contract has been regulated in the past. Graham stresses that the highly-regulated industry exception is premised on the concepts of reliance and unfair surprise, which impose the "burden of uncertainty" on the investor by judging his knowledge of systemic factors. Within the ECtHR, no expectations are reputed to be "legitimate" in highly unstable economic and political environments.

There is also a strong concern towards ensuring the economic viability of investment and the maintenance of property interests. The Supreme Court's reasoning in the Keystone case ${ }^{176}$ can be traced in several ECtHR's judgments, the most relevant of them being the cases dealing with rent control legislation, such as Hutten-Czapska v. Poland ${ }^{177}$ and Amato Gauci v. Malta. ${ }^{178}$ Indeed, in both cases the court found that the low levels of

174 Allied Structural Steel v. Spannaus, 438 US 234 (1978).

175 R. A. Graham, "The Constitution, the Legislature, and Unfair Surprise: Toward a Reliance-Based Approach to the Contract Clause", Michigan Law Review, Vol. 92, 1993, p. 398.

176 Keystone Bituminous Coal Ass'n v. DeBenedictis (supra note 42).

177 Hutten-Czapska v. Poland, Application no. 35014/97, Judgment of 19.6.2006, para. 224.

178 Amato Gauci v. Malta, Application no. 47045/06, Judgment of 15.9.2009, para. 63. See, recently, Bittó and Others v. Slovakia, Application no. 30255/09, Judgment of 28.1.2014, 
rent prevented the landlords from covering the "necessary maintenance expenses" and to "derive profits" from property, which amounted to a violation of art. 1 of Protocol No. 1. This guarantee might be important, in the future, regarding other strains of price regulation measures, like, for instance, the withdrawal of renewable energy support schemes or government interferences with energy prices after market liberalization. ${ }^{179}$

\section{Proportionality and Standards of Review}

As $U$. Kriebaum rightly highlights, ${ }^{180}$ proportionality analysis does not play the same role in both property protection systems. Whereas under the Penn Central's reading of the takings clause, the consideration of the nature and character of the government's action depicts an ontological feature as a requirement for tracing a regulatory taking, in the Human Rights system it is used as a way of assessing the fairness of the government's regulation. In other words, the principle of fair balance, as it is ordinarily called in ECtHR's caseload, is an instrument that, having due regard to the elements of the case - such as the type of interference, the payment of compensation or the general interest pursued - helps to establish whether an individual was asked to bear an excessive burden. ${ }^{181}$

Besides, we have argued that recent developments in Supreme Court's jurisprudence have evinced the intention of reinforcing the protection of investors' expectations, but also of affording greater certainty or predictability to the case-law. The idea is to curb the reserved powers doctrine and simultaneously to restrain the resort to any sort of balancing

para. 113, Krahulec v. Slovakia, Application no. 19294/07, Judgment of 5.7.2016, para. 39, Apap Bologna v. Malta, Application no. 46931/12, Judgment of 30.8.2016, para. 57, Rudolfer v. Slovakia, Application no. 38082/07, Judgment of 5.7.2016, para. 43, Statileo v. Croatia, Application no. 12027/10, Judgment of 10.7.2014, para. 138.

179 A. Boute, "The protection of property rights under the European Convention on Human Rights and the promotion of low-carbon investments", Climate Law, Vol.1, 2010, p. 93; A. Boute, "Regulatory stability under Russian and EU energy law", Maastricht Journal, Vol. 22, 2015, p. 506.

${ }^{180}$ Kriebaum, supra note 26, p. 730.

${ }^{181}$ Padelletti, supra note 83, p. 211. 
exercise or, at least, to keep it within well-defined bounds. Nollan/Dolan introduced a rough proportionality test in land development law and Koontz furthered its scope.

Premised upon different assumptions, the ECtHR also tries to overcome the leniency of the margin of appreciation doctrine by giving teeth to some rather precise and unambiguous obligations. Public authorities are presumed to act in a non-contradictory, consistent and appropriate manner, and non-compliance with these requirements may trigger the duty to compensate. Nonetheless, provided that the legislature remains within the limits of its margin of appreciation, the ECtHR refuses to check whether better alternative measures could have been envisaged. ${ }^{182}$

\section{CONCLUSION}

The study carried out in Parts I and II evinced how two different legal systems deal with the same "constitutional" issue: the impairment of patrimonial interests by a change in law. The fact that international investment law is deeply influenced by the SCOPUS caseload on the "takings" clause paves the way for conflict between investment arbitration and the European Court of Human Rights interpretation of article 1 of Protocol no 1.

Whereas in overtly arbitrary situations, such as in $Y u k o s^{183}-$ a case against Russia assessed both under the auspices of the Energy Charter Treaty and the ECHR - these conflicting features were somewhat blurred (apart from the compensation issue), future cases might emphasize the different inspiration and practical configuration of the limits imposed on governmental action by the multiple legal systems involved ${ }^{184}$.

${ }^{182}$ Da Silva Carvalho v. Portugal (supra note 153), para. 45.

${ }_{183}$ Yukos v. Russia, Application no. 14902/04, Judgment of 20.09.2011; and Yukos v. The Russian Federation, UNCITRAL, PCA Case No. AA 227, Award, 18.07.2014.

${ }^{184}$ See, for instance, M. Fanou, V. Tzevelekos, The shared territory of the ECHR and international investment law, in: Y. Radi (eds.) Research Handbook on Human Rights and Investment, Edward Elgar, 2018, p. 93. 